\title{
Price Variation of Injectable Antibiotics Commonly used in Bharatpur, Chitwan
}

\author{
Ajit Kumar Sah ${ }^{* 1}$, Anish Giri ${ }^{1}$, Anjan Palikhey², Roshan Kumar Chaurasiya ${ }^{1}$, \\ Phoolgen Sah ${ }^{3}$, Mukesh Mallik ${ }^{4}$
}

\author{
'Department of Pharmacology, College of Medical Sciences, Bharatpur, Chitwan, Nepal, \\ 2Department of Pharmacology, Universal College of Medical Sciences, Bhairahawa, Rupandehi, Nepal, ${ }^{3}$ Janmaitri Foundation institute \\ of Health Sciences, Balaju, Kathmandu, Nepal, ${ }^{4}$ College of Medical Sciences, Bharatpur, Chitwan, Nepal
}

\begin{abstract}
Introduction: High dispersion in price of injectable antibiotics makes choice of drugs difficult for the patients and increase economic burden. Thus, objective of this study is to find outrange of price variation of injectable antibiotics commonly used in Bharatpur, Chitwan. Methods: Descriptive observational study of 30 commonly used injectable antibiotics available in medical stores of Bharatpur, Chitwan was done. Range in price variation of the study items of different pharmaceutical companies was calculated in terms of price percentage difference and price ratio by selecting the highest and lowest price. The effect of rise in number of companies for the same drugs over the prices was also studied subjectively based upon graph. Results: We found that the price percentage difference was greatest (204.82\%) for Ceftriaxone $500 \mathrm{mg}$. The maximum retail price of the most expensive brand for Ceftriaxone $500 \mathrm{mg}$ was almost threefold higher than the maximum retail price of the least expensive brand. The growing number of companies also increased dispersion in the price of drugs. Conclusions: There is wide range of price variation of injectable antibiotic commonly used in the Bharatpur, Chitwan. Increasing number of companies in the market has further widened the range. Policy to regulate the price of injectable antibiotic is needed.
\end{abstract}

Keywords: Antibiotics, injectable antibiotics, price range, price variation.

\section{*Correspondence:}

Dr. Ajit Kumar Sah

Lecturer, Department of Pharmacology

College of Medical Sciences, Bharatpur,

Chitwan, Nepal

Email: drajit42@gmail.com

Submitted: April 20, 2021

Accepted: November 16, 2021

To cite: Sah AK , Giri A, Palikhey A, Chaurasiya RK, Sah P, Mallik M. Price Variation of Injectable Antibiotics Commonly used in Bharatpur, Chitwan. G JGMC

Nepal.2021;14(2):137-140.

DOI: $10.3126 /$ jgmcn.v14i2.36522

\section{INTRODUCTION}

Diseases, if left untreated or partially treated, may lead to morbidity or mortality. The reason it is left untreated or partially treated is the high out-of-pocket expenditure (OOPE) on health, which significantly depends upon the price of medicines. Costs of medicines contribute to more than $60 \%$ of health care expenditure, and high prices of drugs lead to therapeutic noncompliance. ${ }^{1,2} \mathrm{~A}$ study reported that drug compliance dropped down by $22 \%$ when OOPE increased by two-fold. ${ }^{3}$ Universal Health Coverage (UHC) provides health security to some level. However, in a low-middle income country like Nepal, it may not be so effective where there is an insurance policy of Nepalese Rupees 100000 per five people per annum. ${ }^{4}$ Doctors generally are unaware of drug prices and likely prescribe expensive drugs of reputed brands. ${ }^{5,6}$ On the patient's side, they doubt the efficacy of cheaper drugs and tend to buy expensive drugs and then discontinue later without completing treatment when the maximum insurance amount is reached. ${ }^{7,8}$

The price of medicine is an important component that influences the compliance of patients with treatment. ${ }^{9}$ Studies have shown that differential pricing of drugs may effectively increase access 
to essential drugs in low-middle income countries where most drugs are purchased through out-of-pocket payment. ${ }^{10}$ Ample of studies are available over differential pricing and cost variation of drugs in many countries. ${ }^{11,12,13}$ However, no such study has been ever done in Nepal, although the same drugs of multiple brands are rampantly sold at varying prices. Therefore, objective of our study is to find the range of price variation of injectable antibiotics of different brands sold in Bharatpur and its association with the number of companies available.

\section{METHODS}

This was a descriptive observational study conducted in the medical stores of Bharatpur, Chitwan, after the approval from Institutional Review Committee of COMSTH, from $1^{\text {st }}$ July 2020 to $31^{\text {st }}$ December 2020 . We observed Bharatpur because it is also a referral center for many other cities nearby and has huge inflow of patients. Medical stores of four referral centers of Bharatpur named Chitwan Medical College, College of Medical Sciences, Bharatpur Hospital, and BP Koirala Memorial Cancer Hospital were used to assess the prices of medicines. This is because these tertiary care hospitals represent majority of patients in Bharatpur due to large patient inflow with variety of diseases and wide range of antibiotics are available here.

We selected 30 commonly used injectable antibiotics for this study. We defined it 'commonly used' because of their availability in Bharatpur during the study and also before the study period. List of injectable antibiotics was explored in the medical market of Bharatpur which underpinned the definition of 'commonly used' antibiotics for medical market of Bharatpur. Therefore, we recognized these 30 items to be commonly used injectable antibiotics. We selected these drugs for the study also because they are used primarily for in-patients and are sold at printed maximum retail price (MRP). Whereas many oral drugs are sold at prices other than MRP. ${ }^{4}$ We expected robust result because selling price of these antibiotics are generally fixed at MRP.

Data was collected by the primary researcher himself. MRP of the selected injectable antibiotics of the same strength and dose manufactured by the different companies were noted from the vial itself. Methods suggested by previous studies were followed to report the variation in MRP., ${ }^{3,4}$ Variation of the prices of the drugs across the pharmaceutical companies was reported in the form of price percentage difference, and Price ratio. We used Software for Statistics and Data Science(STATA) version 15.1 for the calculation of descriptive statistics. We also interpreted the association of price variation with the number of companies available on the basis of eyeball test through graph. Formula used for calculating price percentage difference, and price ratio were as follows:

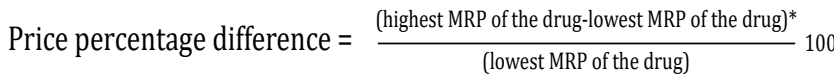

Price ratio $=$ Highest MRP of the drug / Lowest MRP of the drug.

\section{RESULTS}

The variation in MRP of 30 commonly used injectable antibiotics was calculated and presented in figure 1 and table 1 . Among those 30 drugs, five drugs were in combination, while 25 were in a single preparation. Results presented in figure 1 suggest that the price percentage difference of the injectable antibiotics has a positive association with the rise in the number of companies entering the market.

Table1: Price Variation of commonly used Injectable Antibiotics

\begin{tabular}{|c|c|c|c|c|c|c|c|}
\hline Drugs & $\begin{array}{c}\text { Companies } \\
\text { Involved }\end{array}$ & $\begin{array}{l}\text { Mean } \\
\text { MRP } \\
\text { (NRs) }\end{array}$ & Std.Dev & $\begin{array}{l}\text { MRP } \\
\text { Min } \\
\text { (NRs) }\end{array}$ & $\begin{array}{l}\text { MRP } \\
\text { Max } \\
\text { (NRs) }\end{array}$ & $\begin{array}{c}\text { Price } \\
\text { Difference } \\
\text { (\%). }\end{array}$ & Rati \\
\hline $\begin{array}{l}\text { Levofloxacin } 500 \\
\mathrm{mg}\end{array}$ & 5 & 271.6 & 114.49 & 208 & 476 & 128.85 & 2.29 \\
\hline Meropenem $1 \mathrm{Gm}$ & 6 & 1585.27 & 465.29 & 1033.6 & 2312 & 123.68 & 2.24 \\
\hline $\begin{array}{l}\text { Meropenem } 500 \\
\text { mg }\end{array}$ & 5 & 1388 & 605.93 & 960 & 2360 & 145.83 & 2.46 \\
\hline $\begin{array}{l}\text { Metronidazole } \\
500 \mathrm{mg}\end{array}$ & 6 & 41 & 15.77 & 22 & 64 & 190.91 & 2.91 \\
\hline $\begin{array}{l}\text { Moxifloxacin } 400 \\
\text { mg }\end{array}$ & 4 & 252.76 & 70.81 & 189 & 347.44 & 83.83 & 1.84 \\
\hline Ofloxacin $200 \mathrm{mg}$ & 6 & 169.592 & 34.90 & 122 & 208 & 70.49 & 1.70 \\
\hline $\begin{array}{l}\text { Piperacillin+Tazo- } \\
\text { bactam } 4.5 \mathrm{Gm}\end{array}$ & 7 & 550.571 & 331.48 & 331 & 1270 & 283.69 & 3.84 \\
\hline $\begin{array}{l}\text { Piperacillin+Tazo- } \\
\text { bactam } 2.25 \mathrm{Gm}\end{array}$ & 4 & 307.712 & 48.89 & 245 & 349.98 & 42.85 & 1.43 \\
\hline Tigecycline $50 \mathrm{mg}$ & 3 & 4779.33 & 234.79 & 4560 & 5027 & 10.24 & 1.10 \\
\hline $\begin{array}{l}\text { Vancomycin } 500 \\
\text { mg }\end{array}$ & 4 & 465.25 & 89.98 & 370 & 585 & 58.11 & 1.58 \\
\hline Amikacin $100 \mathrm{mg}$ & 5 & 32.8 & 3.83 & 28 & 38 & 35.71 & 1.36 \\
\hline Amikacin $250 \mathrm{mg}$ & 6 & 65.667 & 6.53 & 57 & 72 & 26.32 & 1.26 \\
\hline Amikacin $500 \mathrm{mg}$ & 7 & 119.286 & 7.89 & 110 & 135 & 22.73 & 1.23 \\
\hline $\begin{array}{l}\text { Amoxicillin } 1 \mathrm{Gm} \\
\text { + ClavulanicAcid } \\
200 \mathrm{mg}\end{array}$ & 5 & 192 & 21.01 & 168 & 211 & 25.60 & 1.26 \\
\hline $\begin{array}{l}\text { Azithromycin } \\
500 \mathrm{mg}\end{array}$ & 2 & 326.5 & 2.12 & 325 & 328 & 0.92 & 1.01 \\
\hline Cefazolin $500 \mathrm{mg}$ & 4 & 57.373 & 5.71 & 53.2 & 65.8 & 23.68 & 1.24 \\
\hline Cefazolin $1 \mathrm{Gm}$ & 4 & 90.045 & 6.19 & 82.9 & 95.8 & 15.56 & 1.16 \\
\hline Cefepime $1 \mathrm{Gm}$ & 3 & 285.573 & 85.96 & 232 & 384.72 & 65.83 & 1.66 \\
\hline Cefepime $500 \mathrm{mg}$ & 3 & 249.667 & 57.52 & 193 & 308 & 59.59 & 1.60 \\
\hline Cefotaxime $1 \mathrm{Gm}$ & 8 & 57.976 & 6.19 & 50.05 & 70.4 & 40.66 & 1.41 \\
\hline $\begin{array}{l}\text { Cefotaxime } 500 \\
\mathrm{mg}\end{array}$ & 5 & 31.628 & 5.64 & 22 & 36.6 & 66.36 & 1.66 \\
\hline
\end{tabular}




\begin{tabular}{|c|c|c|c|c|c|c|c|}
\hline Cefotaxim $250 \mathrm{mg}$ & 5 & 25.21 & 5.42 & 18 & 32.58 & 81.00 & 1.81 \\
\hline Ceftriaxone $1 \mathrm{Gm}$ & 9 & 89.999 & 14.22 & 56.08 & 102.8 & 83.31 & 1.83 \\
\hline $\begin{array}{l}\text { Ceftriaxone } 500 \\
\mathrm{mg}\end{array}$ & 8 & 78.381 & 28.67 & 45.04 & 137.29 & 204.82 & 3.05 \\
\hline Ceftriaxone $2 \mathrm{Gm}$ & 5 & 217.48 & 22.22 & 200 & 254 & 27.00 & 1.27 \\
\hline $\begin{array}{l}\text { Ceftriaxone + Sul- } \\
\text { bactum } 1.5 \mathrm{Gm}\end{array}$ & 3 & 225.333 & 23.69 & 198 & 240 & 21.21 & 1.21 \\
\hline $\begin{array}{l}\text { Ceftriaxone }+ \\
\text { Tazobactum } 1.125 \\
\text { Gm }\end{array}$ & 7 & 226.236 & 32.54 & 178.97 & 275 & 53.66 & 1.54 \\
\hline $\begin{array}{l}\text { Ceftriaxone }+ \\
\text { Tazobactum } 562.5 \\
\text { mg }\end{array}$ & 7 & 154.253 & 36.30 & 110.17 & 213.6 & 93.88 & 1.94 \\
\hline $\begin{array}{l}\text { Cefuroxime } 750 \\
\mathrm{mg}\end{array}$ & 6 & 260.72 & 57.92 & 200 & 352 & 76 & 1.76 \\
\hline $\begin{array}{l}\text { Ciprofloxacin } 500 \\
\text { mg } 100 \mathrm{ML}\end{array}$ & 4 & 82 & 4 & 80 & 88 & 10 & 1.1 \\
\hline
\end{tabular}

Note: Diff: Difference; MRP= Maximum retail price; $\mathrm{MIN}=$ Minimum; MAX= Maximum; Std.Dev= standard deviation

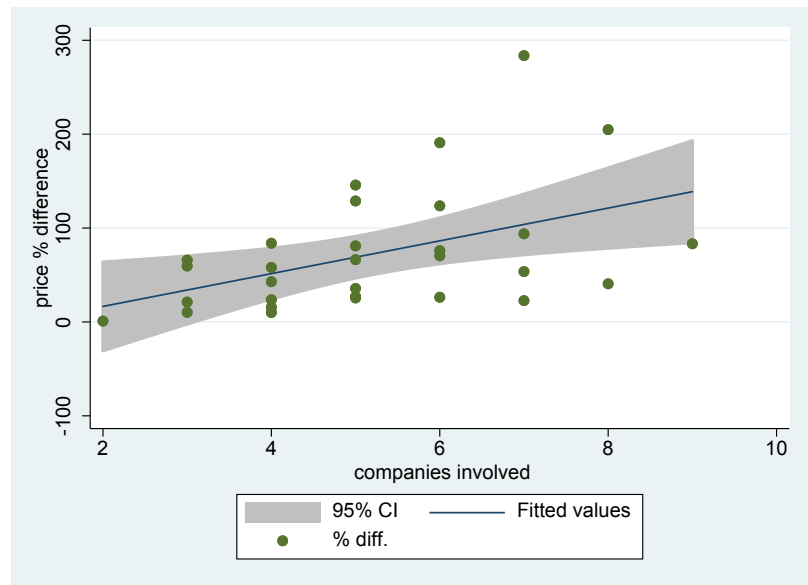

Figure 1: Price variation across number of companies

For single preparation injectable antibiotic, price variation in terms of price percentage difference in table 1 were more than $100 \%$ for levofloxacin $100 \mathrm{ml}$, meropenem of different strengths, and Metronidazole $500 \mathrm{mg}$. Whereas the greatest price percentage difference (204.82\%) was for Ceftriaxone $500 \mathrm{mg}$. Price variation in terms of price ratio suggested that MRP of Ceftriaxone $500 \mathrm{mg}$ was almost three-fold higher for most expensive than least expensive brand.

Among combination drugs, the combination of Piperacillin and Tazobactam 4.5gm costs almost four times more for the most expensive brand than the least expensive brand, although eight companies are available in the market for this drug. Other antibiotics selected for the study did have remarkable price differences between highest and lowest, but they didn't exceed the difference of $100 \%$.

\section{DISCUSSION}

Several studies conducted worldwide suggested that the drugs' price varied with the brand, ultimately impacting the patients. Like India, Nepal provides an open market to the pharmaceutical companies due to which drugs of the same composition and strength are sold under different names and at different prices..$^{8,12,14,15}$ However, limited studies were conducted in Nepal to find out a variation in the drugs' price. Thus, we intended to find out price variation, i.e., dispersion in the price for the injectable antibiotics commonly used. This study's results would help identify the effect of the growing number of companies over variation of price of drugs and would eventually help policymakers control the price to make the drugs accessible at low price by curtailing the expensive companies.

Unlike common belief and evidence provided by the previous study that dispersion in price drops with the rise in companies concentration in the market, we found that dispersion increased with increased pharmaceutical companies' concentration. ${ }^{16}$ We found that the price percentage difference for injectable antibiotics was as high as $284 \%$ and that for the drugs sold by many companies. However, the findings are similar to the study conducted in Palestine and India. ${ }^{1,5,14}$ Hence, we met our objective of finding price variation through this study. In our viewpoint, the reasons for increased price variation despite the growing number of companies may be manifold. First, medical shopping is different from grocery shopping because consumers do not know about the goods that suit them best. Patients buy medicines that clinicians prescribe. Second, the private sector has a stronger hold on Nepal's healthcare market due to the government's low healthcare budget (5.84\% of GDP in 2018), because of which government could not control price. ${ }^{17}$ The marketing policy of companies may influence the decision of doctors while prescribing drugs. Third, the high price of medicine might be of an already existing company, and the low price might be of new companies entering the market, resulting in high price dispersion. Therefore, further study is needed to find the cause of the high dispersion in the price despite the growing number of companies for the same product.

Like many other studies, this study had its strength and limitations. The study's strength was that this was the first study of its type conducted in Nepal for injectable antibiotics. The limitation was that we did not correlate the temporality of the emerging companies and the MRP quoted. It is possible that the brand which entered the market earlier had higher MRP while companies entering later quoted lower MRP due to competition. The newer brand might have a low price resulting in a wide range of price and high price percentage difference. Thus, further study is needed to find whether the rising number of brands in the market can be attributed to the increased 
price of drugs. Nevertheless, a wide variation in price needs to be checked.

\section{CONCLUSIONS}

There is wide range of price variation of injectable antibiotic commonly used in the Chitwan, Nepal. Increasing number of companies in the market has further widened the range. This study suggests that policy to regulate the price of injectable antibiotic is needed in the country so that patients do not have to vacillate while purchasing drugs and added financial burden due to brand of drugs can be avoided.

\section{CONFLICTS OF INTEREST: None Declared}

\section{SOURCE OF FUNDING: None}

\section{REFERENCES}

1. Godwin MS, Varatharajan D. Drug price differentials across different retail market settings. Health Administrator. 2007;19(1):41-7. 2.

2. National Institute of Health Care Management, USA, A Primer: Generic drugs, Patents and the Pharmaceutical Marketplace Available from: http://www.nihcm.org/ GenericsPrimer.pdf [Accessed on 30 ${ }^{\text {th }}$ June 30 2020].

3. Maciejewski ML, Farley JF, Parker J, Wansink D. Copayment reductions generate greater medication adherence in targeted patients. Health affairs. 2010 Nov 1;29(11):2002-8. DOI: 10.1377/hlthaff.2010.0571 PMID: 21041739.

4. Health Insurance Act-2074, Stat. 42 (2017). Available from: https://hib.gov.np/public/uploads/shares/ notice_hib/health-insurance-act-2074.pdf. [Accessed on $30^{\text {th }}$ June 302020$]$.

5. Sweileh W, Jaradat N, Mustafa A. Antibiotic drug cost variations in Palestine: physicians and patients dilemma. An-Najah Univ J Res. 2004;18(1):73-9.

6. Davari M, Khorasani E, Tigabu BM. Factors influencing prescribing decisions of physicians: a review. Ethiopian journal of health sciences. 2018;28(6). DOI: 10.4314/ ejhs.v28i6.15.

7. Bloor K, Maynard A, Freemantle N. Lessons from international experience in controlling pharmaceutical expenditure III: regulating industry. Bmj. $1996 \mathrm{Jul}$ 6;313(7048):33-5. DOI: 10.1136/bmj.313.7048.33.
8. Babar ZU, Ibrahim M Izham M, Bukhari NI. Effect of privatization of the drug distribution system on the prices of anti-infectives in Malaysia. J Pharm Finance Econ Policy. 2004;13:23-6. DOI: 10.1300/ J371v13n03_02

9. Shankar PR, Subish P, Bhandari RB, Mishra P, Saha AC. Ambiguous pricing of topical dermatological products: A survey of brands from two South Asian countries. Journal of Pakistan Association of Dermatologists. 2006;16(3):134-40. 10.

10. Introduction to drug utilization research: World Health Organization; 2003.

11. Mendis S, Fukino K, Cameron A, Laing R, Filipe Jr A, Khatib O, Leowski J, Ewen M. The availability and affordability of selected essential medicines for chronic diseases in six low-and middle-income countries. Bulletin of the world health organization. 2007;85:27988. DOI: 10.2471/BLT.06.033647.

12. Schulman KA, Rubenstein LE, Abernethy DR, Seils DM, Sulmasy DP. The effect of pharmaceutical benefits managers: is it being evaluated? Annals of Internal Medicine. 1996 May 15;124(10):906-13. DOI: 10199605150-00008.

13. Waltermire RD. Direct-to-consumer advertising of Rx drugs can be harmful to your health. Drug Benefit Trends. 1998;10(10):60-1.

14. Roy V, Gupta U, Agarwal AK. Cost of medicines \& their affordability in private pharmacies in Delhi (India). The Indian journal of medical research. 2012 Nov;136(5):827.

15. Monaghan MJ, Monaghan MS. Do market components account for higher US prescription prices? Annals of Pharmacotherapy. 1996 Dec;30(12):1489-94. DOI: $10.1177 / 106002809603001219$.

16. Gerardi KS, Shapiro AH. Does competition reduce price dispersion? New evidence from the airline industry. Journal of Political Economy. 2009 Feb;117(1):1-37. DOI: $10.1086 / 597328$.

17. Current health expenditure ( $\%$ of GDP) - Nepal: The World Bank; 2021. Available from: https:// data.worldbank.org/indicator/SH.XPD.CHEX. GD.ZS?locations=NP. [Accessed on 30 ${ }^{\text {th }}$ June 30 2020]. 